\title{
The Potential of Fractionated Rice Bran Protein Hydrolysates as Antioxidative and Anti-Inflammatory Agents
}

\author{
Wasaporn CHANPUT and Richard LAWYER \\ Department of Food Science and Technology, Faculty of Agro-Industry, \\ Kasetsart University, Bangkok, Thailand
}

(Received June 22, 2019)

\begin{abstract}
Summary Rice bran is generally used as animal feed despite containing numerous nutritional compounds. Small peptides possessing high antioxidant activity can be obtained from rice bran protein via enzymatic hydrolysis. Immune-modulating and antioxidative activity of rice bran protein hydrolysates from crude rice bran protein and its fractions were studied. Albumin, globulin, glutelin, and prolamin proteins were fractionated based on solubility differences and hydrolyzed with two types of enzyme, namely pepsin and protease M. Albumin fraction showed a high degree of hydrolysis in both enzymes. Protease M differently digested rice bran protein fractions, in which it showed low digestion in glutelin and prolamin fractions. After $30 \mathrm{~min}$ of hydrolysis time, the reaction slowed down, and antioxidant activity remained constant in pepsin hydrolysis. Due to the high presence of lipopolysaccharide (LPS) in protease M digested fractions (caused by the enzyme), it could not be used to determine immune-modulating activity. THP-1 macrophages were simultaneously stimulated with $100 \mathrm{ng} / \mathrm{mL}$ LPS and rice bran protein hydrolysates from $4 \mathrm{~h}$ of pepsin digestion. Reduction of pro-inflammatory cytokine IL- $1 \beta$ and increase of anti-inflammatory cytokine IL-10 were observed from crude rice bran protein and albumin. In conclusion, pepsin-digested rice bran protein could be potentially used as antioxidative and anti-inflammatory agent.
\end{abstract}

Key Words protein hydrolysate, protein fractionation, antioxidative activity, immune modulation, THP-1 macrophages

Rice is a principal food staple consumed worldwide, with approximately 650 million metric tons of rice paddies produced annually among Asian countries (IRRI 2012). Nearly one-third of the paddy production is generated from Southeast Asia countries, especially Thailand, Indonesia, and Vietnam (1). Rice bran is primarily comprised of $15-22 \%$ lipids, $34.1-52.3 \%$ of carbohydrates, $7-11.4 \%$ of fiber and $10-16 \%$ of protein. Moreover, antioxidant compounds, such as tocopherol, tocotrienol, and oryzanol are also present (2). Rice bran protein (RBP) is hypoallergenic and contains a high content of lysine, which is the most limiting amino acid in other cereal proteins (3). Rice bran protein digestibility surpasses $90 \%$ with relatively high protein efficiency ratio (PER) values of 2.0 to 2.5 (4). Small peptides derived from rice bran protein via enzymatic hydrolysis also possess antioxidative properties (5). Amino acids in rice bran protein, including histidine, tyrosine, tryptophan, methionine, and lysine also have potent antioxidant activity (6).

Rice bran protein has been classified into four fractions: albumin, globulin, glutelin, and prolamin (7). The globulin fraction showed the strongest antioxidant activity, while the albumin fraction had the greatest reducing capability, as revealed by ferric reducing antioxidant power assay (FRAP) (8). Nineteen antioxidative

E-mail: wasaporn.c@ku.th peptides were isolated from rice bran globulin protein. These peptides were composed of 6-30 amino acid residues with molecular masses ranging from 670-3,611 Da. Their activities have been proposed based on their amino acid compositions and peptide sequences (9).

Free radical accumulation in the body, occurring naturally and through the consumption from external sources, can induce damages on macromolecules, cell membranes, lipids, proteins, and DNA. These incidents can lead into cancer, diabetes mellitus, atherosclerosis, neurodegenerative, inflammatory diseases, and other degenerative diseases. Bioactive peptides from several protein sources reportedly exhibit antimicrobial, antithrombotic, antihypertensive, opioid, immunomodulatory, mineral binding, and antioxidative compounds (10). This research was focused on the antioxidative and anti-inflammatory activities of crude rice bran, fractionated rice bran proteins, and their hydrolysates.

\section{MATERIALS AND METHODS}

Materials. Fresh rice bran variety Oryza sativa L., CV. Khao Dawk Mali 105 was obtained from Patum Rice Mill and Granary Public Co. Ltd., Thailand. The rice bran sample was packed in polyethylene bags and kept at $4^{\circ} \mathrm{C}$ prior to use.

Delipidation of rice bran. Rice bran was ground with a blender and passed through a $50 \mathrm{~mm}$ sieve. Sieved rice bran: hexane ratio of $1: 3(\mathrm{w} / \mathrm{v})$ was defatted twice 
with a laboratory paddle stirrer for $30 \mathrm{~min}$ at room temperature. The slurry was then centrifuged at $10,000 \mathrm{~g}$ at $25^{\circ} \mathrm{C}$ for $30 \mathrm{~min}$. The defatted rice bran was air-dried overnight under a fume hood, and subsequently ground in a blender, sieved through a $50 \mathrm{~mm}$ mesh, and stored at $4^{\circ} \mathrm{C}$ prior to use (4).

Extraction of crude rice bran protein. One hundred grams of defatted rice bran were dispersed in distilled deionized water at ratio of $1: 6(\mathrm{w} / \mathrm{v})$. The $\mathrm{pH}$ was adjusted to 9.5 using a $1.0 \mathrm{~N} \mathrm{NaOH}$ solution, stirred with a paddle stirrer for $30 \mathrm{~min}$, then centrifuged at $10,000 \times g$ for $30 \mathrm{~min}$ at $25^{\circ} \mathrm{C}$. The supernatant was adjusted to $\mathrm{pH} 4.5$ with a $1.0 \mathrm{~N} \mathrm{HCl}$ solution and centrifuged again at $10,000 \mathrm{~g}$ for $30 \mathrm{~min}$ at $25^{\circ} \mathrm{C}$. The precipitate was being washed with distilled deionized water ( $\mathrm{pH} 4.5$ ) prior to freeze-drying (11). Protein content was determined with the Kjeldahl method (12). The freeze-dried rice bran protein powder was stored at $-20^{\circ} \mathrm{C}$ until needed.

Fractionation of rice bran protein. One hundred grams of defatted rice bran were fractionated according to Osborne method as described in the previous study (8). Each supernatant obtained from the four fractions (albumin, globulin, prolamin, and glutelin) was adjusted with a $0.1 \mathrm{M} \mathrm{HCl}$ solution to its specific isoelectric points (pI): $\mathrm{pH} 4.1,4.3,5.0$, and 4.8 respectively. The precipitated proteins were collected by centrifugation at $10,000 \mathrm{~g}$ for $30 \mathrm{~min}$ and freeze-dried. Protein content was determined using the Kjeldahl method (12). All fractions were freeze-dried and stored at $-20^{\circ} \mathrm{C}$ until used.

Hydrolysis of crude rice bran protein and rice bran protein fractions. One gram (dry basis) of freeze-dried crude rice bran protein and fractionated rice bran protein samples (albumin, globulin, prolamin or glutenin) were suspended in distilled water $(1 \% \mathrm{w} / \mathrm{v})$ and adjusted to $\mathrm{pH} 2$ and $\mathrm{pH} 3$ for pepsin (E.C.3.4.23.1, 1,120 units/ $\mathrm{mg}$ ) and protease M (E.C.232-752-2, 500 units/g) digestion respectively. Protein solutions for pepsin digestion were mixed using a $1: 100$ protein: enzyme $(\mathrm{w} / \mathrm{w})$ ratio and incubated at $37^{\circ} \mathrm{C}$, while1: 25 ratio and $50^{\circ} \mathrm{C}$ incubation $(\mathrm{w} / \mathrm{w})$ was applied for protease $\mathrm{M}$ digestion (8). Sample aliquots were collected and digested for 0.5 , 1,2 , and $4 \mathrm{~h}$. The enzymes were inactivated by water bath heating at $95^{\circ} \mathrm{C}$ for $3 \mathrm{~min}$. These hydrolyzed protein solutions were kept at $4^{\circ} \mathrm{C}$ for a month before use.

Determination of degree of hydrolysis. The O-phthalaldehyde (OPA) method, as described in referenced study (13), determined the degree of hydrolysis (DH). The OPA reagent was prepared by combining: $25 \mathrm{~mL}$ of $100 \mathrm{~mm}$ sodium tetraborate, $2.5 \mathrm{~mL}$ of $20 \% \mathrm{w} / \mathrm{w}$ of SDS and $40 \mathrm{mg}$ of OPA (dissolved in $1 \mathrm{~mL}$ of methanol), and $100 \mu \mathrm{L}$ of $\beta$-mercaptoethanol. Distilled water was added to final volume of $50 \mathrm{~mL}$. The reagent was prepared fresh before use. An aliquot of protein hydrolysate $(50 \mu \mathrm{L})$ was added directly to $2 \mathrm{~mL}$ of OPA reagent in a quartz cuvette. The solution was thoroughly mixed and incubated for $2 \mathrm{~min}$ at ambient temperature. Absorbance was measured at $340 \mathrm{~nm}$ via spectrometer. The following equation determined the percentage of degree hydrolysis:

$\%$ Degree of hydrolysis $=($ Mw. $\Delta 340 \mathrm{~nm}) /(\mathrm{d} . \varepsilon . \mathrm{p}) \times 100$

Where $\mathrm{Mw}$ is the average molecular weight of amino acids (=120), $\Delta 340 \mathrm{~nm}$ is the absorbance at $340 \mathrm{~nm}, \mathrm{~d}$ is the dilution factor, $\varepsilon$ is the constant value $(6,000$ $\left.\mathrm{m}^{-1} \mathrm{~cm}^{-1}\right)$, and $\mathrm{p}$ is protein concentration $(\mathrm{mg} / \mathrm{mL})$.

Determination of protein content. The Biuret reagent consists of $2.25 \mathrm{~g}$ of sodium potassium tartrate, $0.75 \mathrm{~g}$ of copper sulfate $\left(\mathrm{CuSO}_{4} \cdot 5 \mathrm{H}_{2} \mathrm{O}\right)$, and $1.25 \mathrm{~g}$ of potassium iodide, dissolved in $100 \mathrm{~mL}$ of $0.2 \mathrm{M} \mathrm{NaOH}$ solution. The solution volume was then adjusted to $250 \mathrm{~mL}$ with distilled water. Five milliliters of biuret reagent were mixed with $1 \mathrm{~mL}$ samples at room temperature for $30 \mathrm{~min}$. The standard protein solution was prepared using bovine serum albumin (BSA) at 1 to $10 \mathrm{mg} / \mathrm{mL}$ concentrations. Absorbance was determined at $540 \mathrm{~nm}$ (8).

Determination of total phenolic compound. Gallic acid between 200 to $2,000 \mu \mathrm{g} / \mathrm{mL}$ was used in preparaing the standard solutions. The mixture contained $50 \mu \mathrm{L}$ of either the standard or sample solution, $250 \mu \mathrm{L}$ of freshly prepared Folin-Ciocalteau reagent, and $3 \mathrm{~mL}$ of distilled water. After being mixed thoroughly, the mixtures were left at room temperature for $10 \mathrm{~min}$, then $750 \mu \mathrm{L}$ of $20 \%$ sodium carbonate solution was added. The solution was mixed again and incubated for $2 \mathrm{~h}$ at $25^{\circ} \mathrm{C}$. Absorbance at $765 \mathrm{~nm}$ was measured via spectrometer (14).

Antioxidative activity of rice bran protein hydrolysates. The 2,2-azino-bis (3-ethylbenzothiazoline-6-sulphonic acid) (ABTS) solution was dissolved in $50 \mathrm{~mL}$ of phosphate buffer saline (PBS). The $\mathrm{pH}$ was adjusted to 7.4 with $\mathrm{NaOH}$. A $70 \mathrm{mM} \mathrm{K} \mathrm{S}_{4} \mathrm{O}_{8}$ solution was prepared with distilled water. An ABTS radical cation was created by reacting $10 \mathrm{~mL}$ of the ABTS stock solution with $40 \mu \mathrm{L}$ of the $\mathrm{K}_{2} \mathrm{~S}_{4} \mathrm{O}_{8}$ solution and subsequently stored in dark place at room temperature for 16-17 h before use (15). Hydrolysate antioxidant activity at $1 \mathrm{mg}$ protein/mL was analyzed using the methodology described in the aforementioned study (16).

Endotoxin quantification assay. The amount of lipopolysaccharide (LPS) in all rice bran samples was determined using ToxinSensor ${ }^{\mathrm{TM}}$ Chromogenic LAL Endotoxin Assay Kit (GenScript, USA.).

Anti-inflammatory activity. The macrophage-like state was obtained by treating THP-1 monocyte with $100 \mathrm{ng} / \mathrm{mL}$ phorbol 12-myristate 13-acetate (PMA; Sigma) for $48 \mathrm{~h}$ in 24-well cell culture plates with $0.5 \mathrm{~mL}$ of cell suspension $\left(5 \times 10^{5}\right.$ cells $)$. To achieve macrophage resting state, differentiated and adherent cells were washed twice with the culture medium (RPMI 1640 medium without PMA but containing 10\% FBS and $1 \% \mathrm{P} / \mathrm{S}$ ) and rested in culture medium for another $24 \mathrm{~h}$. THP-1 macrophages were stimulated for $12 \mathrm{~h}$ with rice bran protein hydrolysates derived from $4 \mathrm{~h}$ of 50, 100 and $200 \mu \mathrm{g} / \mathrm{mL}$ pepsin digestion together with LPS from E. coli at $100 \mathrm{ng} / \mathrm{mL}$. The concentrations of IL- $1 \beta$, TNF- $\alpha$ and IL-10 in cell culture supernatant were measured using enzyme-linked immunosorbent assay (ELISA) (Abnova, Taiwan). 
Table 1. Protein content and yield of crude rice bran protein and fractionated rice bran proteins.

\begin{tabular}{lcc}
\hline \multicolumn{1}{c}{ Fraction } & \%Protein & \%Protein yield \\
\hline Defatted rice & 18.76 & - \\
Crude rice bran protein & 74.29 & 8.80 \\
Albumin & 73.48 & 1.61 \\
Globulin & 92.57 & 1.97 \\
Glutelin & 77.78 & 5.36 \\
Prolamin & 59.08 & 0.36 \\
\hline
\end{tabular}
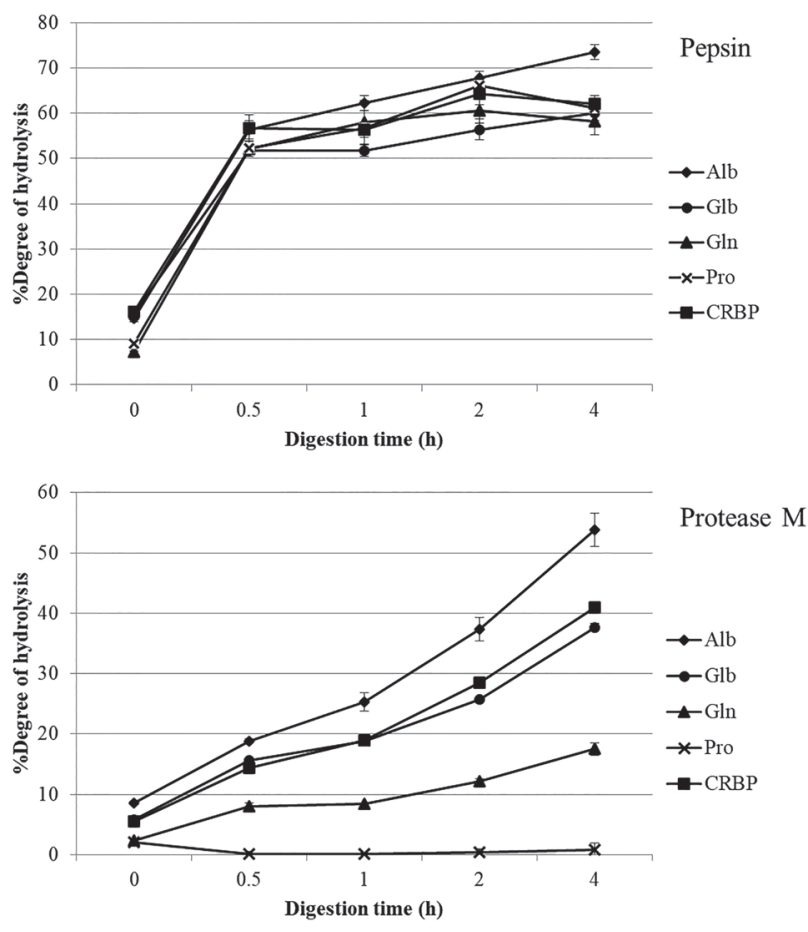

Fig. 1. \%Degree of hydrolysis (\%DH) of crude rice bran protein (CRBP), albumin (Alb), globulin (Glb), glutenin (Gln) and prolamin (Pro) digested by pepsin and protease M. Values are means \pm standard deviation (SD) from two independent replications.

Statistical analysis. Two independent and duplicate replications were performed for all analyses (except protein extraction). All data were reported as means with standard deviation (SD). Dunnett's multiple comparison test revealed post-hoc statistical differences from the control with confidence interval of $95 \%$.

\section{RESULTS}

\section{Protein extraction and fractionation}

The Khao Dawk Mali 105 defatted rice bran variety contained $18.76 \%$ protein. The protein content (dry basis) and yield (calculated from defatted rice bran) for each fraction are shown in Table 1. Protein content ranged from 59-92\% with crude rice bran protein yielding the greatest amount and prolamin the least. \%Degree of hydrolysis

Pepsin and protease $M$ digestion was used for crude rice bran protein $(\mathrm{CRBP})$ and fractionated rice bran pro-


Fig. 2. Protein concentrations in supernatants of crude rice bran protein (CRBP), albumin (Alb), globulin (Glb), glutenin (Gln) and prolamin (Pro) digested by pepsin and protease M. Values are means \pm standard deviation (SD) from two independent replications.

tein enzymatic hydrolysis. The\%degree of hydrolysis (\%DH) during digestion with pepsin increased sharply for all protein samples during the first $30 \mathrm{~min}$, while in protease $\mathrm{M}$ hydrolysis increased exponentially for up to $4 \mathrm{~h}$ of digestion (except for prolamin) (Fig. 1). Pepsin and protease $\mathrm{M}$ produced the greatest digestibility in albumin and CRBP among five protein fractions.\%DH increased in samples passed through similar digestive conditions without additional enzymes were not found (data not shown).

Protein content and total phenolic compound

The concentrations of supernatant protein over time post enzymatic hydrolysis are shown in Fig. 2. Pepsin hydrolysates had greater supernatant protein concentrations compared to protease M digestion. Protein concentrations in glutelin and prolamin hydrolysate supernatants due to pepsin digestion were the highest, while those of protease M were the lowest. Strangely, protein content in globulin supernatant without the addition of pepsin and protease $\mathrm{M}$ was increased as much as with the presence of enzyme (data not shown).

Generally, hydrolysate phenolic concentrations from pepsin digestion were significantly higher than those of protease M hydrolysates (Fig. 3). Glutelin hydrolysate from pepsin digestion showed the greatest TPC content, followed by prolamin, albumin, CRBP, and globulin, respectively. The greatest TPC in protease $\mathrm{M}$ occurred in albumin, while prolamin had the least TPC content. The TPC and protein concentration trends in both enzymes were relatively similar. 

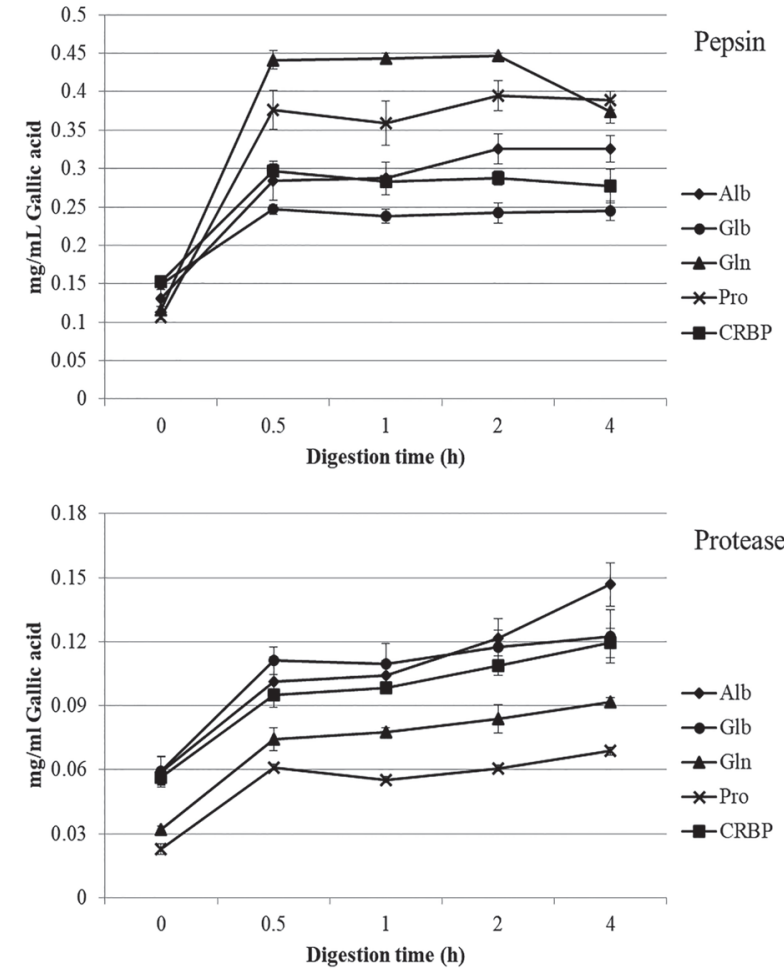

Fig. 3. Total amount of supernatant phenolic compounds of crude rice bran protein (CRBP), albumin (Alb), globulin (Glb), glutenin (Gln) and prolamin (Pro) digested by pepsin and protease M. Values are means \pm standard deviation (SD) from two independent replications.
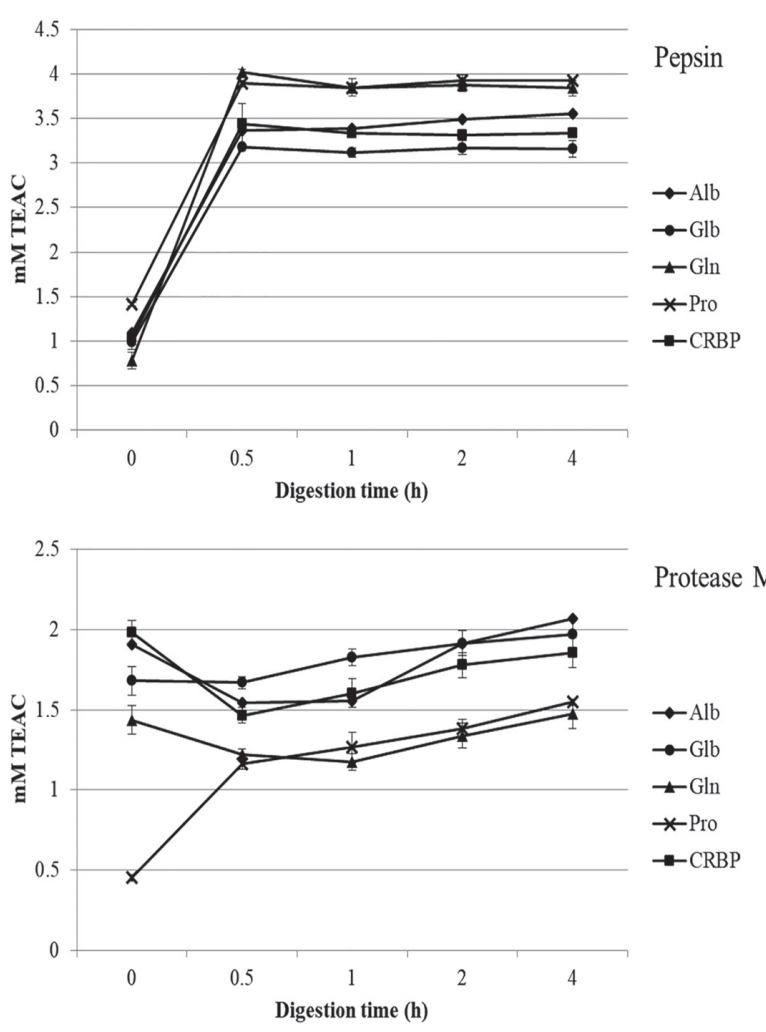

Fig. 4. Antioxidative activity of crude rice bran protein (CRBP), albumin (Alb), globulin (Glb), glutenin (Gln) and prolamin (Pro) hydrolysates from pepsin and protease $\mathrm{M}$ digestion. Values are means \pm standard deviation (SD) from two independent replications.

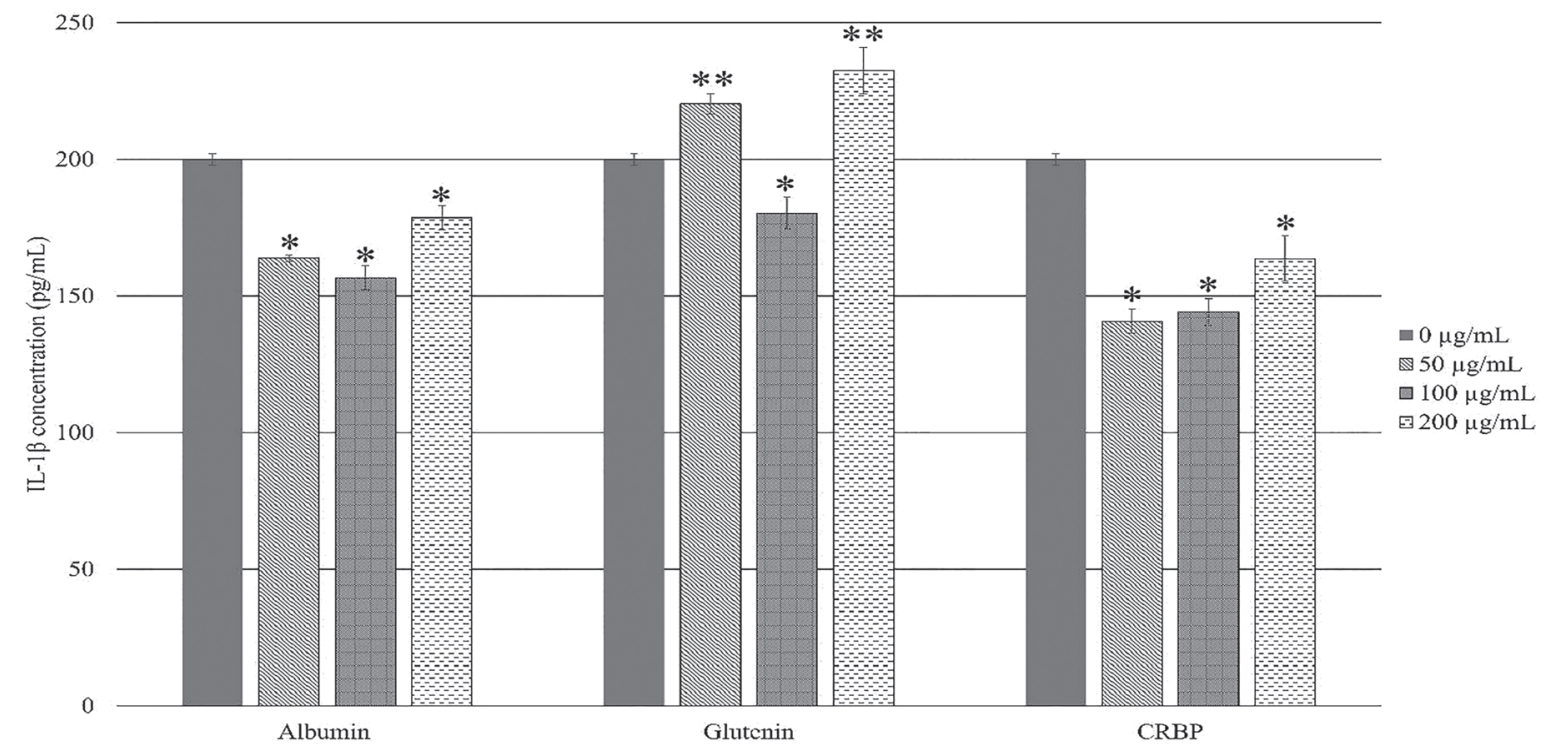

Fig. 5. IL-1 $\beta$ cytokine concentration (pg/mL) of LPS-stimulated THP-1 macrophages simultaneously-incubated with $100 \mathrm{ng} / \mathrm{mL}$ LPS and 4h-pepsin digested albumin, glutelin, and CRBP hydrolysates at protein concentrations of 0,50 , 100 , and $200 \mu \mathrm{g} / \mathrm{mL}$. Value are means \pm standard deviation (SD) from two independent replications. One and two asterisks imply statistically difference at a confidence interval of $95 \%$ for lower and higher.

\section{Antioxidant activity}

Antioxidant activity was determined by ABTS radical scavenging activity and expressed as Trolox equivalent antioxidant capacity (TEAC) (Fig. 4). All protein hydrolysates concentrations were adjusted to $1 \mathrm{mg}$ protein/
mL. Protein hydrolysates obtained from pepsin digestion possessed greater antioxidant capacities than those from protease $\mathrm{M}$ digestion. Interestingly, sharp antioxidant activity increase correlated positively to the degree of hydrolysis during the first $30 \mathrm{~min}$ of pepsin diges- 


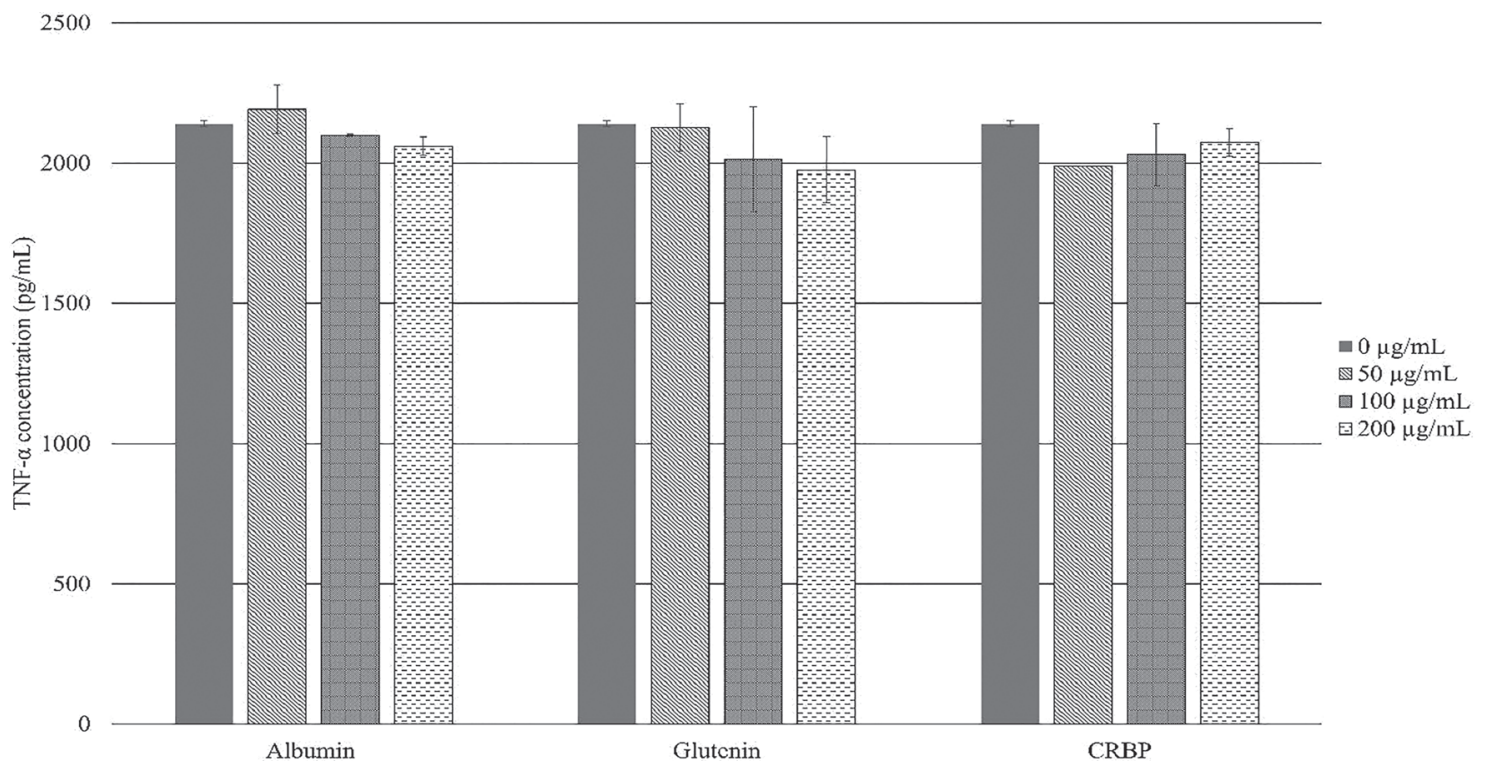

Fig. 6. TNF- $\alpha$ cytokine concentration (pg/mL) of LPS-stimulated THP-1 macrophages incubated with 4 h-pepsin digested albumin, glutelin, and CRBP hydrolysates at protein concentrations of $0,50,100$, and $200 \mu \mathrm{g} / \mathrm{mL}$. Values are means \pm standard deviation (SD) from two independent replications. No statistically difference was found among different concentrations in the same hydrolysate.

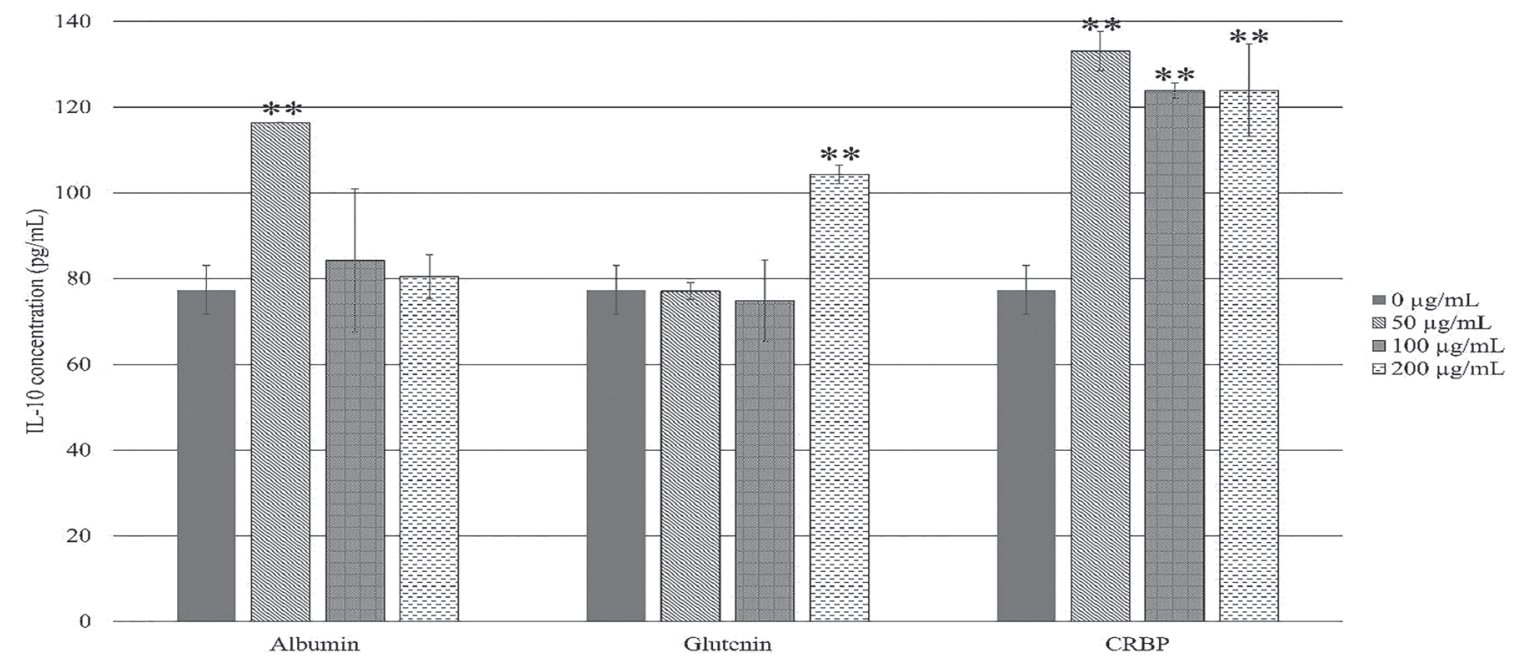

Fig. 7. IL-10 cytokine concentrations (pg/mL) of LPS-stimulated THP-1 macrophages incubated with 4h-pepsin digested albumin, glutelin hydrolysates, and CRBP hydrolysates at protein concentrations of $0,50,100$, and $200 \mu \mathrm{g} / \mathrm{mL}$. Values are means \pm standard deviation (SD) from two independent replications. Two asterisks show statistically difference at a confident interval of $95 \%$.

tion. The greatest antioxidant activity among all treatments appeared in glutelin and prolamin hydrolysates from pepsin digestion. Hydrolysates by protease $\mathrm{M}$ showed no discernible trend between antioxidant capacity and degree of hydrolysis.

Endotoxin quantification assay

LPS concentrations from pepsin digestion at 50, 100, and $200 \mu \mathrm{g} / \mathrm{mL}$ concentrations in all protein hydrolysates were ranged from $0.22-0.30 \mathrm{ng} / \mathrm{mL}$. Our preliminary study revealed that THP-1 macrophages showed no pro-inflammatory gene expression with LPS concentrations below $10 \mathrm{pg} / \mathrm{mL}$. LPS contamination in protein hydrolysates from protease $\mathrm{M}$ digestion were approxi- mately $30-80 \mu \mathrm{g} / \mathrm{mL}$. This might be due to the detection of high LPS concentration in the protease M enzyme. Consequently, anti-inflammatory activity could not be further tested in hydrolysates from protease $\mathrm{M}$ using THP-1 macrophages.

Anti-inflammatory activity

Hydrolysates from $4 \mathrm{~h}$ of pepsin digestion; CRBP, albumin, and glutelin were simultaneously applied to $100 \mathrm{ng} / \mathrm{mL}$ LPS and 0, 50, 100, and $200 \mu \mathrm{g} / \mathrm{mL}$ protein concentration to stimulate THP-1 macrophages. Due to the minute quantities of the prolamin fraction and the digestion of globulin without addition of pepsin or protease M (data not shown), the anti-inflammatory 
activity of these two protein fractions could not be determined. Cytokine concentrations were investigated after $12 \mathrm{~h}$ of incubation via an enzyme-linked immunosorbent assay (ELISA). As shown in Fig. 5, IL-1 $\beta$ production decreased for CRBP and albumin hydrolysates in a non-dose dependent manner, while in glutelin increased.

There were no significant differences in the decrease of TNF- $\alpha$ concentrations for all treatments (Fig. 6). It is very interesting to observe the significantly increase of IL-10 production after LPS-stimulated THP-1 macrophages were simultaneously incubated with CRBP, albumin and glutelin hydrolysates for $12 \mathrm{~h}$ (Fig. 7).

\section{DISCUSSION}

Albumin is the most abundant fraction in rice bran protein, followed by globulin, glutenin, and prolamin, respectively (17). In our findings, CRBP had the greatest $\%$ protein yield with $8.80 \%$, followed by glutenin at $5.36 \%$, similar to the results of Wang et al. (18) and Wattanasiritham et al. (19). This is due to the alkaline condition in CRBP extraction and pI precipitation of approximately 4.5 (11). Alkaline extraction is commonly used for protein extraction in food industries. The abundance of disulphide bonds in rice bran produces cross-links between phytic acid, cellulose, and other molecular compounds, including protein. This results in low protein extraction yield (14).

Pepsin was effective in digesting all five fractions; CRBP, albumin, globulin, prolamin, and glutelin, while the protease $\mathrm{M}$ resulted in selective digestion with a little impact on glutelin and prolamin fractions. Adebiyi et al. (7) indicated that Hitomebore rice glutelin and prolamin fractions were more resistant to protease enzymatic hydrolysis. Rice bran protein albumin fractions had the greatest protease digestibility due to its solubility in water (7), which may result in desirable protein functional properties such as water holding capacity, emulsifying, and foaming activities (18). Biuret protein quantifying method is used to determine protein concentration based on the complex bonding between cupric ions and peptide bonds (20). Pepsin-digested hydrolysates produced greater supernatant protein concentrations than those from protease M. This corresponded to the greater degree of hydrolysis in rice bran protein fractions from pepsin than that of protease M. It could be explained that the proteolytic actions of protease $\mathrm{M}$ enzyme are endoprotease and exoprotease activity, while pepsin is only endoprotease cleaving peptide bonds in the interior of polypeptide chain $(7,17)$. Therefore, more free amino acids are expected to be released into the supernatant of protease $M$ than that of pepsin digestion.

Rice bran protein digestion released phenolic compounds previously embedded within the protein matrix (21). Total phenolic compounds (TPC) correlated positively with protein content in the supernatant. Protease $\mathrm{M}$ hydrolysates, with a lower degree of hydrolysis in digesting rice bran protein, produced less TPC than pepsin. Also, higher temperature of $50^{\circ} \mathrm{C}$ for protease $\mathrm{M}$ enzymatic digestion compared to $37^{\circ} \mathrm{C}$ for pepsin, resulted in the degradation of heat-sensitive phenolic compounds. Rice bran protein hydrolysates from pepsin and protease $\mathrm{M}$ contained between $0.02-0.45 \mathrm{mg} \mathrm{GAE} /$ mL of TPC. Zhou and Yu (14) quantified TPC in Akron wheat bran extract at approximately $2.63 \mathrm{mg} \mathrm{GAE} / \mathrm{g}$, while sorghum had $5 \mathrm{mg}$ GAE/g (22) The TPC of rice bran protein hydrolysates in this study was notably lower than extracts from other cereals. Thus, antioxidative activity and anti-inflammatory activity from rice bran protein hydrolysates may come from peptides released from rice bran protein and not from phenolic compounds. According to the results of Chen et al. (23) and Tironi et al. (24), antioxidative activity could be completely lost when peptides cleave to free amino acids. This may explain on low antioxidative activity of protease M-digested rice bran protein hydrolysates. Wattanasiritham et al. (19) demonstrated typical characteristics of antioxidative peptides from fractionated rice bran protein hydrolysates. Trypsin-hydrolyzed rice bran albumin exhibited the highest antioxidant activity with ORAC value. It is worth to be noted that antioxidative activity of rice bran protein is highly depended on types of digesting enzyme, hydrolysis time and rice bran protein fraction.

Rice bran protein hydrolysates after $4 \mathrm{~h}$ pepsin digestion decreased pro-inflammatory cytokine IL- $1 \beta$ secretion and, interestingly, promoted anti-inflammatory IL-10 secretion. This indicates remarkable anti-inflammatory activity of rice bran hydrolysates in LPS-THP-1 macrophage stimulated model. Boonloh et al. (25) extracted crude rice bran protein followed by digestion with commercial enzyme Protease G6. The hydrolysate was given to obese mice with low-grade inflammation over the course of $6 \mathrm{wk}$. The degree of pro-inflammatory cytokines IL-6, TNF- $\alpha$, and iNOS in the liver were reduced. Moreover, rice bran protein hydrolysates showed signs of insulin resistance (26) and a response in glycemic lowering effect (27). The antioxidative activity of rice bran protein hydrolysates are derived by scavenging reactive oxygen species (28). During inflammation, ROS production increases in immune cells to eliminate foreign substances. Thus, one anti-inflammatory activity of pepsin-hydrolyzed rice bran protein may result from radical scavenging activity. However, antioxidative and anti-inflammatory activities seemed not to be correlated in our findings. Another proposed anti-inflammatory activities from cereal proteins include the suppression of the NF- $k B$ pathway $(29,30)$, resulting in decreased pro-inflammatory cytokines and mediator production in macrophages. These two mechanisms are also present in egg and milk peptidesanti-inflammatory activities (31).

\section{CONCLUSION}

Pepsin-digested crude rice bran protein and albumin hydrolysates are potentially useful as antioxidative and anti-inflammatory agents based on in vitro research concerning in LPS-stimulated THP-1 macrophages. These two protein fractions may also provide easy to 
digest protein sources in food additives.

\section{Disclosure of state of COI}

The authors declared no conflict of interest in the findings of this manuscript.

\section{Acknowledgments}

The authors would like to sincerely thank Kasetsart University Research and Development Institute for the funding support for young researchers in the fiscal year 2013.

\section{REFERENCES}

1) Acmissah J, Ellis W, Oduro I, Manful J. 2003. Nutrient composition of bran from new rice varieties under study in Ghana. Food Control 14(1): 21-24.

2) Fcabian C, Ju Y-H. 2011. A review on rice bran protein: its properties and extraction methods. Crit Rev Food Sci Nutr 51(9): 816-827.

3) Schih F, Champagne E, Daigle K, Zarins Z. 1999. Use of enzymes in the processing of protein products from rice bran and rice flour. Food/Nahrung 43(1): 14-18.

4) Wcang M, Hettiarachchy N, Qi M, Burks W, Siebenmorgen T. 1999. Preparation and functional properties of rice bran protein isolate. J Agric Food Chem 47(2): 411416.

5) Acdebiyi AP, Adebiyi AO, Ogawa T, Muramoto K. 2008. Purification and characterisation of antioxidative peptides from unfractionated rice bran protein hydrolysates. Int J Food Sci Technol 43(1): 35-43.

6) Scaito K, Jin D-H, Ogawa T, Muramoto K, Hatakeyama E, Yasuhara T, et al. 2003. Antioxidative properties of tripeptide libraries prepared by the combinatorial chemistry. J Agric Food Chem 51(12): 3668-3674.

7) Acdebiyi AP, Adebiyi AO, Hasegawa Y, Ogawa T, Muramoto K. 2009. Isolation and characterization of protein fractions from deoiled rice bran. Eur Food Res Technol 228(3): 391-401.

8) Cchanput W, Theerakulkait C, Nakai S. 2009. Antioxidative properties of partially purified barley hordein, rice bran protein fractions and their hydrolysates. $J$ Cereal Sci 49(3): 422-428.

9) Pcihlanto-Leppälä A. 2000. Bioactive peptides derived from bovine whey proteins: opioid and ace-inhibitory peptides. Trends Food Sci Technol 11(9-10): 347-356.

10) Shcarma S, Singh R, Rana S. 2011. Bioactive peptides: a review. Int J Bioautomation 15(4): 223-250.

11) Gncanasambandam R, HelTiarachchy N. 1995. Protein concentrates from unstabilized and stabilized rice bran: preparation and properties. J Food Sci 60(5): 10661069.

12) AOcAC. 1995. Official Methods of Analysis. 16 ed. Arlington, VA, USA: AOAC International.

13) Chcurch FC, Swaisgood HE, Porter DH, Catignani GL. 1983. Spectrophotometric Assay Using o-Phthaldialdehyde for Determination of Proteolysis in Milk and Isolated Milk Proteins1. J Dairy Sci 66(6): 1219-1227.

14) Zhcou K, Yu L. 2004. Effects of extraction solvent on wheat bran antioxidant activity estimation. LWT Food Sci Technol 37(7): 717-721.

15) Macrrufo-Estrada DM, Segura-Campos MR, Chel-Guerrero LA, Betancur-Ancona DA. 2013. Defatted Jatropha curcas flour and protein isolate as materials for protein hydrolysates with biological activity. Food Chem 138(1):
77-83.

16) Rec R, Pellegrini N, Proteggente A, Pannala A, Yang M, Rice-Evans C. 1999. Antioxidant activity applying an improved ABTS radical cation decolorization assay. Free Radic Biol Med 26(9): 1231-1237.

17) Hacmada J. 2000. Characterization and functional properties of rice bran proteins modified by commercial exoproteases and endoproteases. J Food Sci 65(2): 305310.

18) Wacng C, Xu F, Li D, Zhang M. 2015. Physico-chemical and structural properties of four rice bran protein fractions based on the multiple solvent extraction method. Czech J Food Sci 33: 283-291.

19) Wacttanasiritham L, Theerakulkait C, Wickramasekara S, Maier CS, Stevens JF. 2016. Isolation and identification of antioxidant peptides from enzymatically hydrolyzed rice bran protein. Food Chem 192: 156-162.

20) Zocu TB, He TP, Li HB, Tang HW, Xia EQ. 2016. The Structure-Activity Relationship of the Antioxidant Peptides from Natural Proteins. Molecules 21(1): 72.

21) Sacpan CV, Lundblad RL, Price NC. 1999. Colorimetric protein assay techniques. Biotechnol Appl Biochem 29(2): 99-108.

22) Awcika JM, Rooney LW, Wu X, Prior RL, Cisneros-Zevallos L. 2003. Screening methods to measure antioxidant activity of sorghum (Sorghum bicolor) and sorghum products. J Agric Food Chem 51(23): 6657-6662.

23) Chcen H, Zhao M, Lin L, Wang J, Sun-Waterhouse D, Dong Y, et al. 2015. Identification of antioxidative peptides from defatted walnut meal hydrolysate with potential for improving learning and memory. Food Res Int 78: $216-223$.

24) Ticroni VA, Añón MC. 2010. Amaranth proteins as a source of antioxidant peptides: Effect of proteolysis. Food Res Int 43(1): 315-322.

25) Booncloh K, Kukongviriyapan V, Kongyingyoes B, Kukongviriyapan U, Thawornchinsombut S, Pannangpetch P. 2015. Rice bran protein hydrolysates improve insulin resistance and decrease pro-inflammatory cytokine gene expression in rats fed a high carbohydrate-high fat diet. Nutrients 7: 6313-6329.

26) Mattchews DR, Hosker JP, Rudenski AS, Naylor BA, Treacher DF, Turner RC. 1985. Homeostasis model assessment: insulin resistance and $\beta$-cell function from fasting plasma glucose and insulin concentrations in man. Diabetologia 28(7): 412-419.

27) Mlincar B, Marc J, Janež A, Pfeifer M. 2007. Molecular mechanisms of insulin resistance and associated diseases. Clinica Chimica Acta 375(1): 20-35.

28) Cerratco C, Langel Ü. 2018. Effect of a Fusion Peptide by Covalent Conjugation of a Mitochondrial Cell-Penetrating Peptide and a Glutathione Analog Peptide.

29) de Mejica EG, Dia VP. 2009. Lunasin and lunasin-like peptides inhibit inflammation through suppression of NF- $\kappa \mathrm{B}$ pathway in the macrophage. Peptides 30(12): 2388-2398.

30) Hernándezc-Ledesma B, Hsieh C-C, de Lumen BO. 2009. Antioxidant and anti-inflammatory properties of cancer preventive peptide lunasin in RAW 264.7 macrophages. Biochem Biophys Res Commun 390(3): 803808.

31) Huang W, Schen S, Nimalaratne C, Li S, Majumder K, Wu J. 2012. Effects of addition of egg ovotransferrinderived peptides on the oxygen radical absorbance capacity of different teas. Food Chem 135(3): 1600-1607. 